\title{
Muenke Syndrome
}

National Cancer Institute

\section{Source}

National Cancer Institute. Muenke Syndrome. NCI Thesaurus. Code C84904.

A rare autosomal dominant inherited disorder caused by mutations in the FGFR3 gene. It

is characterized by premature fusion of cranial bones, resulting in head shape abnormalities, flattened cheekbones, and wide-set eyes. 